\title{
Green Manure Species for Phytoremediation of Soil With Tebuthiuron and Vinasse
}

\section{OPEN ACCESS}

Edited by:

Eric D. van Hullebusch, Université de Paris, France

Reviewed by:

Edmilson Ambrosano,

Sao Paulo Agency of Agribusiness and Technology (APTA), Brazil

Ramdas Kanissery,

University of Florida, United States

*Correspondence:

Paulo Renato Matos Lopes prm.lopes@unesp.br

Specialty section:

This article was submitted to

Bioprocess Engineering,

a section of the journal

Frontiers in Bioengineering and

Biotechnology

Received: 02 October 2020 Accepted: 10 November 2020

Published: 05 January 2021

Citation:

Ferreira LC, Moreira BRA, Montagnolli RN, Prado EP, Viana RS, Tomaz RS, Cruz JM, Bidoia ED, Frias YA and Lopes PRM (2021) Green Manure

Species for Phytoremediation of Soil With Tebuthiuron and Vinasse. Front. Bioeng. Biotechnol. 8:613642. doi: 10.3389/fbioe.2020.613642

\section{Luziane Cristina Ferreira ${ }^{1}$, Bruno Rafael de Almeida Moreira ${ }^{1}$, Renato Nallin Montagnolli ${ }^{2}$, Evandro Pereira Prado ${ }^{1}$, Ronaldo da Silva Viana ${ }^{1}$, Rafael Simões Tomaz', Jaqueline Matos Cruz ${ }^{3}$, Ederio Dino Bidoia ${ }^{3}$, Yanca Araujo Frias ${ }^{1}$ and Paulo Renato Matos Lopes ${ }^{1 *}$}

${ }^{1}$ Department of Plant Production, College of Technology and Agricultural Sciences, São Paulo State University (UNESP), Dracena, Brazil, ${ }^{2}$ Department of Natural Sciences, Mathematics and Education, Agricultural Sciences Center, Federal University of São Carlos (UFSCar), Araras, Brazil, ${ }^{3}$ Department of Biochemistry and Microbiology, Biosciences Institute, São Paulo State University (UNESP), Rio Claro, Brazil

Tebuthiuron is often used to control weed growth in sugarcane cultures. This herbicide is highly toxic and can persist in soil for up to 2 years according to its degradation half-life. Hence, its residual effect is highly hazardous for the environment and local habitants via leaching, surface runoff. Screening out of species of green manure as potential phytoremediators for tebuthiuron in soil, with and with no vinasse, accordingly is the scientific point of this study. Green manure species selected for the trial in greenhouse were jack bean [Canavalia ensiformis (L.) DC.], pigeon pea [Cajanus cajan (L. Millsp.)], velvet bean [Mucuna pruriens (L.) DC.)], and millet [Pennisetum glaucum (L.) R.Br.], and Crotalaria juncea $\mathrm{L}$. as bioindicator of this herbicide. The determination/quantification of height, stem diameter, and number of leaves in all plants were monitored, as well as other morphological traits for drafting any inference on biomass production. Moreover, ecotoxicity bioassays were performed from soil samples at the beginning and at the end of the experiment. Results showed preliminary evidence of effective phytoremediation capacity by $M$. pruriens and $P$. glaucum in soils with tebuthiuron, as the growth of C. juncea was sustained. Both Gompertz approach and principal component analysis predicted that these green manure species could grow healthier and for longer periods in soils containing tebuthiuron and vinasse and, thus, reduce physiological anomalies due to ecotoxicity. The implications of this study may aid in the implementation of cost-effective strategies targeting decontamination of tebuthiuron in sugarcane crops with vinasse application in fertigation.

Keywords: bioremediation, ecotoxicity, fertigation, herbicide, sugarcane

\section{INTRODUCTION}

Sugarcane is affected by weeds, despite its highly efficient photosynthetic pathway $\left(\mathrm{C}_{4}\right)$ that promotes adequate development, especially in its early stages. Weeds compete for available soil resources and therefore undermine agricultural yields (Victoria Filho and Christoffoleti, 2004; Sandaniel et al., 2008). 
The planting of sugarcane takes place in wide open areas so that high productivity is achieved, aided by technological tools for the proper weed management as herbicides (Kuva et al., 2008; Oliveira and Brighenti, 2011). Such chemical method is the first choice of agricultural producers due to its ease of access, availability, and low operational costs, compared to other control techniques (Kuva et al., 2008).

Among the herbicides commercialized for sugarcane, tebuthiuron is the most used, whose selective pre-emergent action controls main weeds in the crop (Moraes et al., 2016). This molecule [1-(5-tert-butyl-1,3,4-thiadiazol-2-yl)-1,3dimethylurea] has a systemic action and acts in the inhibition of photosystem II (Breitenbach et al., 2001). However, tebuthiuron can cause environmental damage since it is considered dangerous to the environment due to its high persistence and long half-life in the environment, moderate to extreme toxicity (Rodrigues and Almeida, 2011), low sorting capacity in soil (Koskinen et al., 1996), and high solubility in water (Franco-Bernardes et al., 2014). Hence, residual concentration is an extremely important factor, as it results in a greater potential for contamination. Therefore, successive applications without proper management can make its potential for impact even greater on soil and groundwater (Christofoletti et al., 2017).

Vinasse can also be applied to farmlands as growth-inducing agents, as opposed to herbicides. Vinasse is one of the many byproducts of sugar production also found in alcohol distilleries in enormous quantities. It is highly applicable as fertilizer during crop production (Andrade, 2007). It is considered a residue from the alcohol production, generated at a 10-14:1 ratio (Assad, 2017). The outstandingly large amount of vinasse generated everyday highlights its expressive polluting potential and, therefore, demands the development of proper disposal protocols. However, vinasse can also be used to enrich soils due to its nutritional value. Still, its environmental effects combined with herbicides are yet to be determined.

The cleaning up process of areas with previous pesticides release is not simple, but fortunately, many solutions have been improved in the past decades. Feasible solutions should follow four requirements, as proposed by Ferro et al. (1994): (i) high decontamination efficiency, (ii) straightforward execution, (iii) fast and reliable protocols, and (iv) cost effectiveness. Bioremediation is as an ecologically viable strategy that meets such requirements during the treatment of impacted areas by organic pollutants. The acceleration of natural biological processes that reduce the concentration and toxic effects of polluting agents is the core of all bioremediation strategies (Fasanella and Cardoso, 2016).

Phytoremediation further expands this definition by using plants to reduce the toxicity of contaminants in the environment (Ali et al., 2013). Research related to this technique seeks to understand the plant-contaminant interactions that may lead to full pollutant removal (Vasconcellos et al., 2012). Therefore, the plants must be capable of absorbing toxic elements in the soil to promote decontamination (Souza et al., 2011).

Pires et al. (2008) reported that millet (Pennisetum typhoides), velvet bean (Stizolobium aterrimum), Jack bean (Canavalia ensiformis), and pigeon pea (Cajanus cajan) were highly effective toward tebuthiuron phytoremediation. They used sunn hemp (Crotalarea juncea) as the bioindicator plant. Several studies reinforce this approach, as many authors have observed a decrease in pesticides concentration in soils by using phytoremediation (Pires et al., 2003, 2005, 2006; Pires et al., 2008; Madalão et al., 2013; Melo et al., 2017).

However, there is a major drawback in all those studies: the toxicity of these samples has not been quantified before and after the treatments. The degradation of organic compounds could potentially generate intermediate compounds that are often more toxic than the original formulation (Rocha et al., 2018). We argue that it is imperative to evaluate the ecotoxicological potential in a broader time-dependent approach to demonstrate the success of bioremediation strategies (Banks and Schultz, 2005).

In this context, we evaluated the potential of four plant species to remediate soil samples contaminated with tebuthiuron and the effects of vinasse in the process.

\section{MATERIALS AND METHODS}

Experiments were set up in a greenhouse located at the College of Agricultural and Technological Sciences, Sao Paulo State University (Unesp), Dracena, São Paulo, Brazil, with geographical coordinates of $21^{\circ} 28^{\prime} 57^{\prime \prime} \mathrm{S} 51^{\circ} 31^{\prime} 58^{\prime \prime} \mathrm{W}$ and $400 \mathrm{~m}$ elevation.

According to the Köppen (1948) classification, the regional climate type is Aw (tropical humid). The average local temperature and precipitation are $22.1^{\circ} \mathrm{C}$ and $1,200 \mathrm{~mm}$, respectively. The meteorological data were provided by our own station (Dracena EMA/FCAT).

The observations occurred between May and July 2019. The average temperature and relative humidity were $22.6^{\circ} \mathrm{C}$ and $62.9 \%$, respectively, also obtained from the Dracena EMA/FCAT weather station.

\section{Soil, Vinasse, and Tebuthiuron Sampling}

The regional soil is a dystrophic red-yellow argisol type according to the classification proposed by Santos et al. (2018). The physical analysis revealed that it is composed of $89.9 \%$ sand, $7.1 \%$ clay, and $3.0 \%$ silt.

The soil has the following chemical characteristics: phosphorus, $5 \mathrm{mg} / \mathrm{dm}^{3}$; organic matter, $3 \mathrm{mg} / \mathrm{dm}^{3} ; \mathrm{pH}$ 5.2; potassium, $1.7 \mathrm{mmolc} / \mathrm{dm}^{3}$; calcium, $15 \mathrm{mmolc} / \mathrm{dm}^{3}$; magnesium, $4 \mathrm{mmolc} / \mathrm{dm}^{3} ; \mathrm{H}+\mathrm{Al}, 13 \mathrm{mmolc} / \mathrm{dm}^{3}$; CTC, $34 \mathrm{mmolc} / \mathrm{dm}^{3}$; sum of bases, $21 \mathrm{mmolc} / \mathrm{dm}^{3}$; and base CTC saturation (V\%), 61\%. This characterization served as a basis to the optimal fertilizing conditions in our pots for all the proposed species.

Fertilizer dosages per pot were set individually to meet each species needs. We applied $80 \mathrm{~g}$ of urea diluted in $1.5 \mathrm{~L}$ of water, divided into three applications, in Pennisetum glaucum (L.) R.Br. We applied $8 \mathrm{~g}$ of urea diluted in $4.5 \mathrm{~L}$ of water, applied only once at sowing, in legumes [C. ensiformis (L.) DC., C. cajan (L. Millsp.), Mucuna pruriens (L.) DC.]. For all other pots, we added $125 \mathrm{~g}$ of $\mathrm{KCl}$ diluted in $6 \mathrm{~L}$ of water, divided into three applications, and $445 \mathrm{~g}$ of simple super phosphate to $320 \mathrm{~L}$ of soil, necessary 
TABLE 1 | Morphological aspects of green manure species in soil with tebuthiuron and vinasse.

\begin{tabular}{|c|c|c|c|c|}
\hline Species & \multicolumn{4}{|c|}{ Test } \\
\hline C. cajan & $64.40 \mathrm{Aa}$ & $49.20 \mathrm{Bb}$ & $\mathrm{ND}^{*}$ & $\mathrm{ND}^{*}$ \\
\hline C. ensiformis & $75.00 \mathrm{Aa}$ & $64.80 \mathrm{Bb}$ & $N D^{*}$ & $\mathrm{ND}^{*}$ \\
\hline M. pruriens & $125.80 \mathrm{Aa}$ & $134.60 \mathrm{Aa}$ & $115.50 \mathrm{Aab}$ & $44.00 \mathrm{Bb}$ \\
\hline P. glaucum & \multicolumn{4}{|c|}{ Diameter, mm } \\
\hline C. cajan & $5.40 \mathrm{Ba}$ & $4.69 \mathrm{Bb}$ & $\mathrm{ND}^{*}$ & $\mathrm{ND}^{*}$ \\
\hline C. ensiformis & $5.65 \mathrm{Ba}$ & $5.60 \mathrm{Bb}$ & $N D^{*}$ & $N D^{*}$ \\
\hline M. pruriens & $5.05 \mathrm{Ba}$ & $5.05 \mathrm{Ba}$ & 4.45 Bab & $3.50 \mathrm{Bb}$ \\
\hline P. glaucum & $52.70 \mathrm{Aa}$ & $42.30 \mathrm{Aa}$ & $35.90 \mathrm{Aa}$ & $23.15 \mathrm{Ab}$ \\
\hline P. glaucum & $22.50 \mathrm{Aa}$ & $20.80 \mathrm{Aa}$ & $20.50 \mathrm{Aa}$ & $16.30 \mathrm{Ba}$ \\
\hline
\end{tabular}

Same letters, whether uppercase in the column and lowercase in the row, describe statistically similar means by post hoc Tukey's HSD test at $p<0.05$;.

${ }^{*}$ As the plant dead, the trait became undetected (ND).

for filling the pot total volume. The volume of each vessel was $4 \mathrm{dm}^{3}$.

The vinasse was collected from a sugar-energy plant in the Dracena-SP region using sterile glass bottles. The vinasse was subsequently stored in a refrigerator at $4^{\circ} \mathrm{C}$ until its use in the experimental units preparation (stored for 3 days).

The herbicide tebuthiuron was provided by Combine ${ }^{\circledR}$ 500SC-Dow AgroSciences Industrial Ltd.

\section{Plant Species}

The plant species were chosen according to their capability to remediate pesticide-contaminated soils. Their agricultural potential to improve overall soil quality was another criterion. We narrowed our plants selection to species that are often found as green manure and/or forage in the rotation of the sugarcane cultures. Thus, we used the following species: pigeon pea (C. cajan), jack bean ( $C$. ensiformis) (Madalão et al., 2013, 2016), velvet bean ( $M$. pruriens) (Pires et al., 2005, 2008), and millet (P. glaucum) (Pires et al., 2008).

\section{Experimental Setup}

We designed the experiments according to a randomized blocks approach at a $2 \times 2 \times 4$ factorial scheme with five repetitions. The parameters were tebuthiuron concentration, vinasse volume, and the four plant species.

The treatments are further referred to in this paper as indicated in the brackets: [T-], absence of tebuthiuron; $[\mathrm{T}+]$, presence of tebuthiuron; $[\mathrm{V}-]$, absence of vinasse; and $[\mathrm{V}+]$ presence of vinasse.

\section{Preparation of Experimental Units}

Experimental units (pots $4 \mathrm{dm}^{3}$ and their contents) were filled with soil and received the four potentially phytoremediating species. Treatments containing vinasse had to undergo manual compound application to endure homogeneity. The vinasse was added first, at $150 \mathrm{~m}^{3} \mathrm{ha}^{-1}\left(150 \mathrm{ml} \mathrm{dm}^{-3}\right)$, following the CETESB Technical Standard P4.231/2005 (2005) on the procedures to apply vinasse to agricultural soils.

The Combine ${ }^{\circledR} 500$ SC was sprayed at the following day, at $2 \mathrm{~L} \mathrm{ha} \mathrm{h}^{-1}$ as the recommended rate of this herbicide in sugarcane crops, using a $\mathrm{CO}_{2}$ pressurized sprayer (Herbicat ${ }^{\circledR}$ ) equipped with six XR 8002 flat jet nozzles at a pressure of 2 bar ( $0.65 \mathrm{~L} \mathrm{~min}^{-1}$ flowrate) from a minimum distance of $0.5 \mathrm{~m}$. The application was carried out $0.75 \mathrm{~m}$ above the pots at a constant speed $\left(5 \mathrm{~km} \mathrm{~h}^{-1}\right)$ until $250 \mathrm{~L} \mathrm{ha}^{-1}$ had been applied. Environmental conditions such as temperature and relative humidity were monitored at the time of spraying using a portable digital thermo-hygro-anemometer-luximeter (Instrutherm ${ }^{\circledR}$ model THAL-300). The spraying occurred inside our greenhouse to avoid wind interference during the application. An equivalent volume of deionized water was added to treatments without vinasse and/or tebuthiuron.

Finally, 10 seeds per pot were sown the day after the tebuthiuron application. Thinning was performed on the eight DAS to keep only one plant per pot. These were irrigated daily by microsprinklers for $60 \mathrm{~min}(30 \mathrm{~min}$ at 6:00 a.m. and $30 \mathrm{~min}$ at 6:00 p.m.) to ensure adequate conditions for plant growth.

The cultivation of species with phytoremediation potential was performed for 50 days. Therefore, the final phytoremediation evaluation time for these plants is $t_{50}$.

Ten days after harvesting the plants of these species, we sowed 10 seeds of the bioindicator species sunn hemp (C. juncea $\mathrm{L}$ ). 

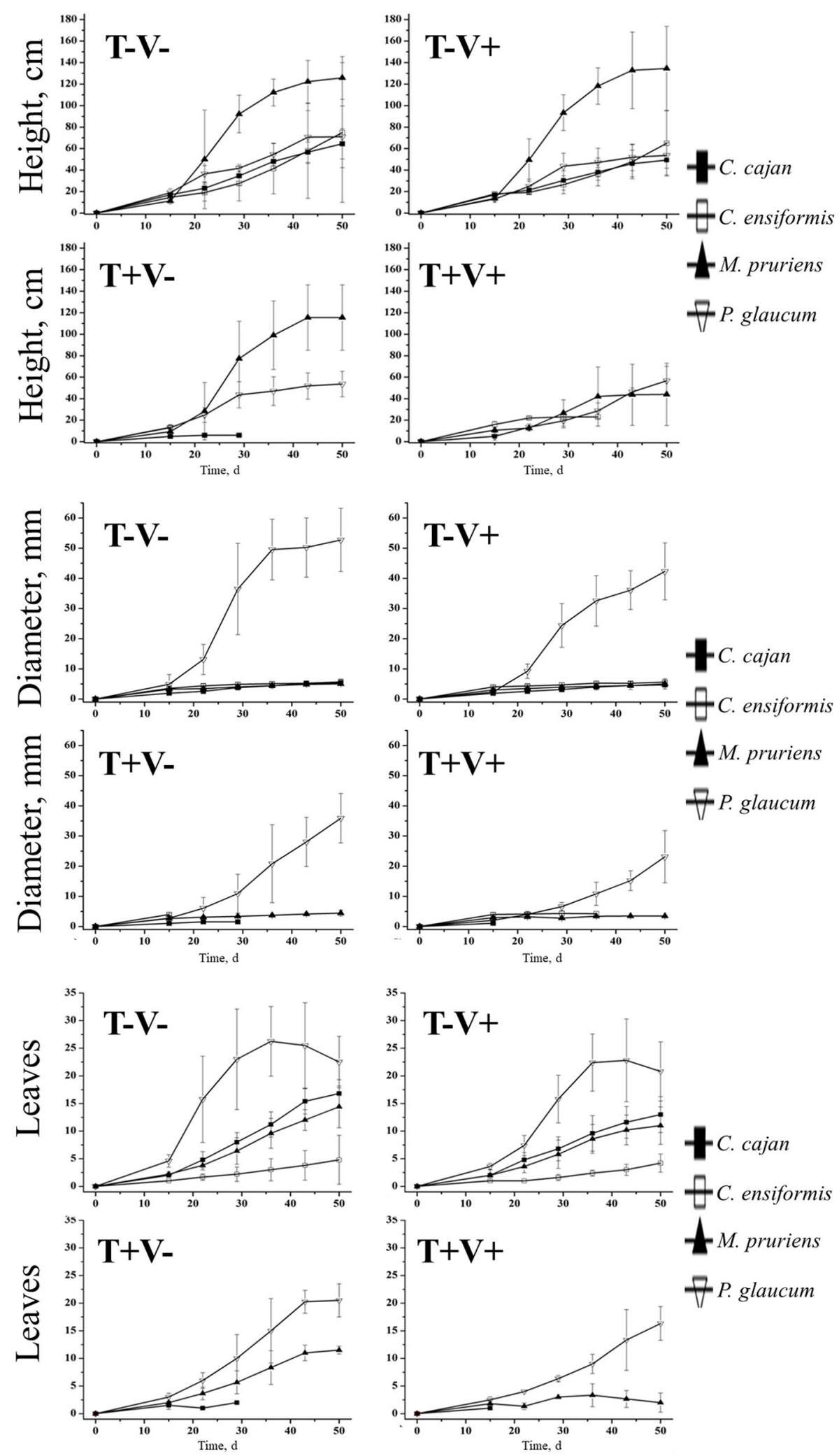

FIGURE 1 | Production of biomass by green manure species in soil with tebuthiuron and vinasse. 


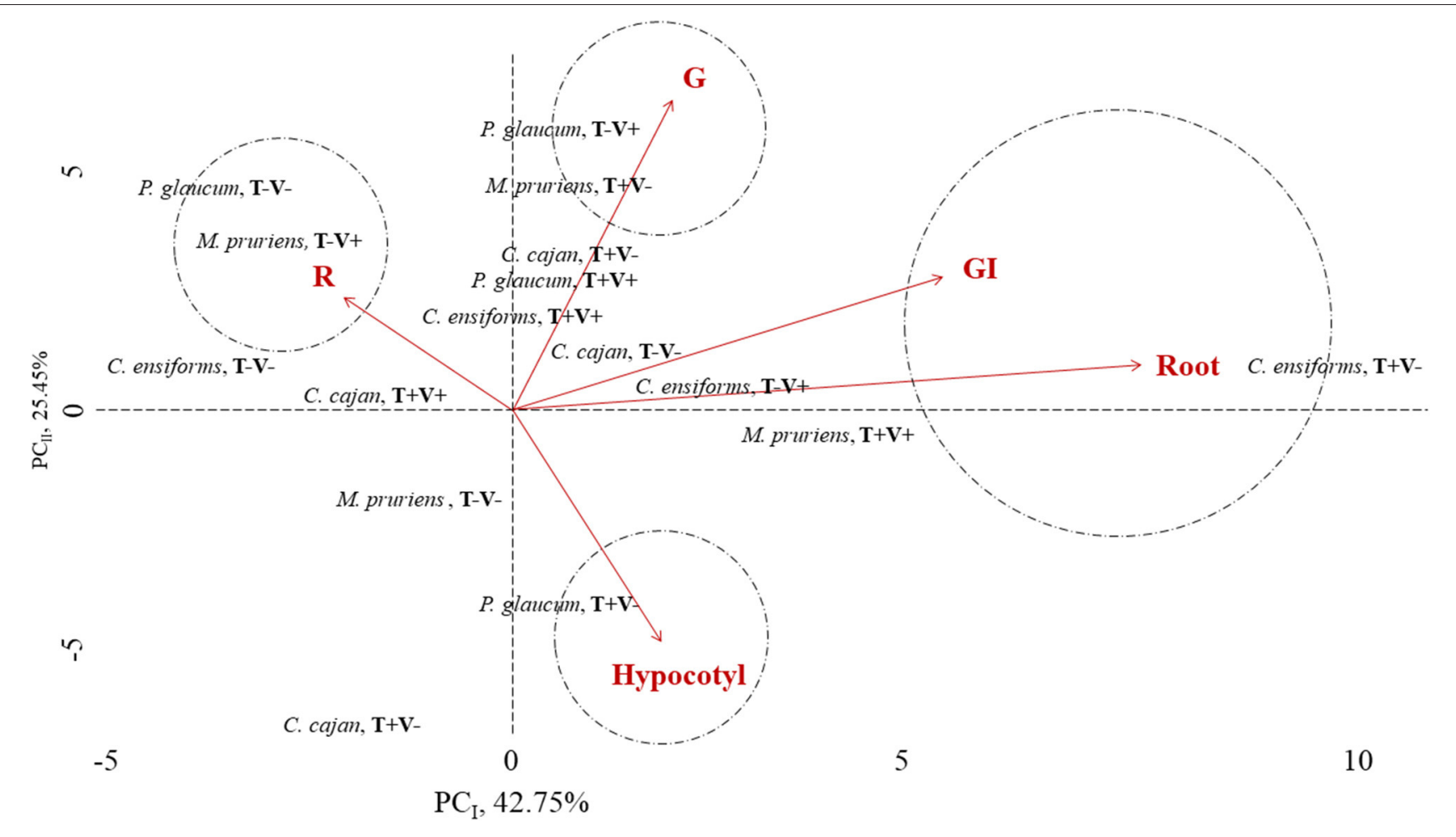

FIGURE 2 | Kinetics of growth and development of green manure species in soil with tebuthiuron and vinasse.

Thinning was performed on the 10th DAS. These were also irrigated daily by microsprinkling at $6 \mathrm{~mm} / \mathrm{h}$ for $60 \mathrm{~min}(30 \mathrm{~min}$ at 6:00 A.M. and $30 \mathrm{~min}$ at 6:00 P.M.) to sustain proper plant development conditions.

\section{Evaluation of Plant Growth}

Plant growth was quantified weekly. The monitored parameters were (i) stem diameter in millimeter, (ii) height of shoot in centimeter, and (iii) number of leaves.

For C. cajan, C. ensiformis, $M$. pruriens, and $P$. glaucum, the periodic monitoring running from the 15th to the 50th DAS yielded six time-point datasets until the end $\left(t_{50}\right)$ of cultivation. C. juncea was planted in all experimental units, and its morphological parameters were monitored from 17 th to the 45th DAS, thus yielding five time-point datasets until the end of experiment $\left(t_{95}\right)$.

After cultivation, plants were separated for quantification of biomass: the fresh and dry matter of shoots and roots. The separation of the shoots and roots occurred by cutting the stalks close to the soil between the stem and the root. The roots were thoroughly washed so that all the soil was removed. After separation, each fraction was weighed separately and then packed in a paper bag to dryness in oven at $65^{\circ} \mathrm{C}$, over $72 \mathrm{~h}$. The resulting samples were weighted again to obtain the dry mass.

\section{Ecotoxicity Bioassays}

Bioassays monitored the ecotoxicological potential of each treatment over the proposed time frame. The phytotoxicity of the soil samples was determined at the initial $\left(\mathrm{t}_{0}\right)$ and final $\left(\mathrm{t}_{50}\right)$ times when it was cultivated the phytoremediation species (C. cajan, $C$. ensiformis, M. pruriens, and $P$. glaucum), just before the $C$. juncea introduction.

Lettuce seeds (Lactuca sativa) were the test organism, according to Sobrero and Ronco (2004). Phytotoxic effect determination of each treatment was performed in six replicates from the solubilized soil extract, according to the NBR 10.006 (ABNT, 2004).

Ecotoxicity tests were prepared in Petri dishes with filter paper supported with $2.0 \mathrm{ml}$ of the solubilized extract and 10 lettuce seeds. Petri dishes were then wrapped with polyvinyl chloride (PVC) film and incubated at $20 \pm 2{ }^{\circ} \mathrm{C}$ for $120 \mathrm{~h}$ in the dark.

Positive control was prepared using $0.05 \mathrm{M}$ zinc sulfate to inhibit seed germination and negative control using deionized water to test the base germination and growth values of the seeds (Sobrero and Ronco, 2004).

The following parameters were determined: seed germination, root and hypocotyl elongation $(\geq 0.1 \mathrm{~mm})$, and the Germination Index (GI) that combines seed germination ( $\% \mathrm{G})$ and root elongation (\% R) at the CN. The GI was used to assess the toxicity 
TABLE 2 | Kinetic parameters for the growth and development of green manure species in soil with tebuthiuron and vinasse.

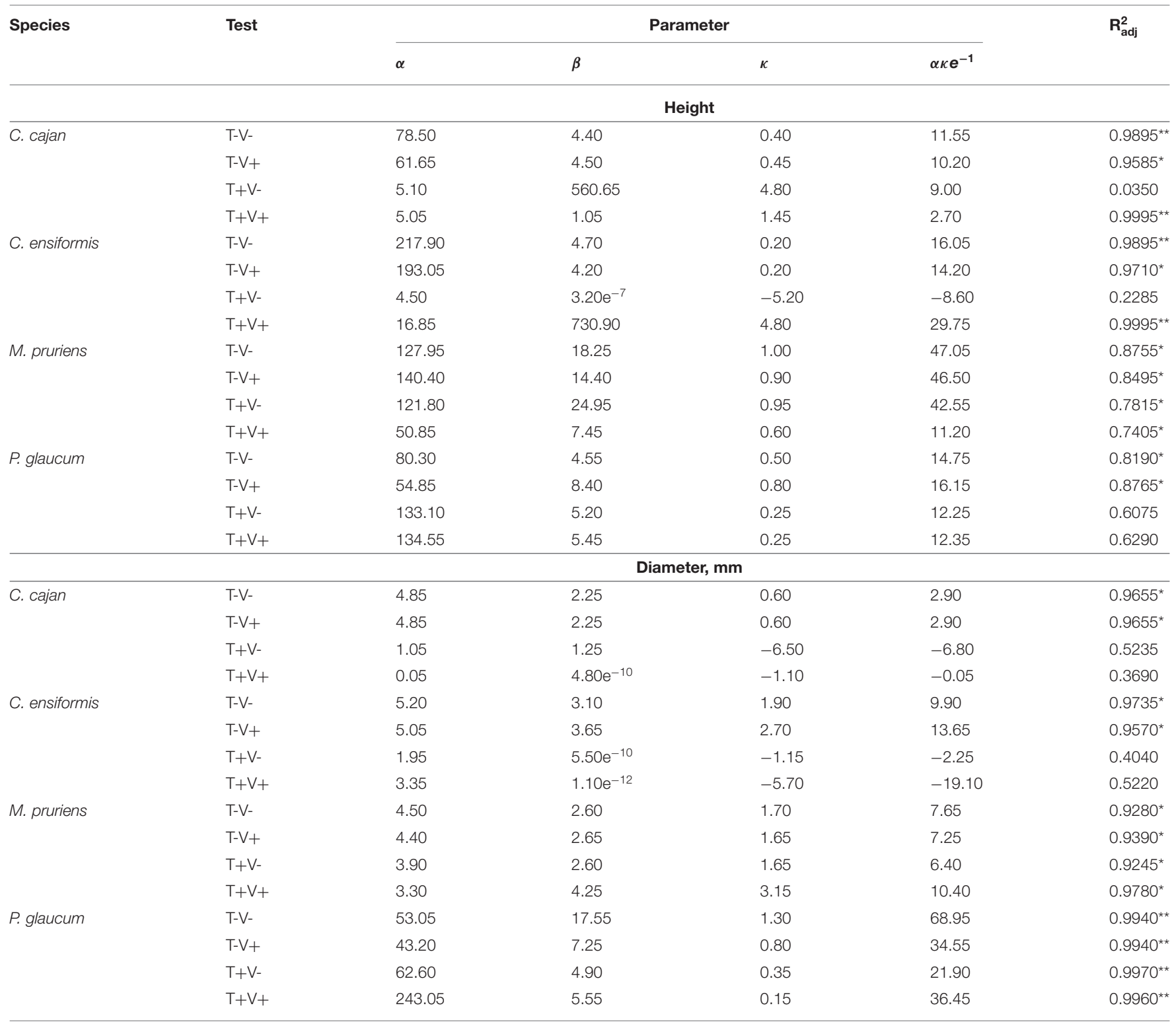

Significant code: ${ }^{* *} p<0.01 ;{ }^{*} p<0.05$.

of soil samples in the test organism, according to Equation 1 (Labouriau and Agudo, 1987):

$$
G_{I}=\frac{G \times R}{100}
$$

\section{Data Analysis}

Procedures of Shapiro-Wilk and Bartlett checked the normalcy and homoscedasticity of the dataset, respectively, and the analysis of variance tested the significance of effect of factors on the soil phytoremediation. The tests were separated by post hoc Tukey's honest significant difference (HSD) test. The data of temporal variability were fitted for Gompertz (Equation 2). This stochastic model has probability density function enough to predict how long would it take the green manure in soil with tebuthiuron and stillage to reach the maximum of growth and develop and stop. The kinetic parameters, $\alpha, \beta$, and $\kappa$, will assist in drafting inferences about the potential phytoremediators and figuring out the best chance to deal with how to solve the side effects of these contaminants as much suitably as possible.

$$
f=\alpha e^{-\beta e^{-k x}}
$$

where:

$\mathrm{f}(x)$ : height or stem diameter;

$x$ : time of sampling;

$\alpha$ : upper asymptote or the maximum of height or stem diameter; 


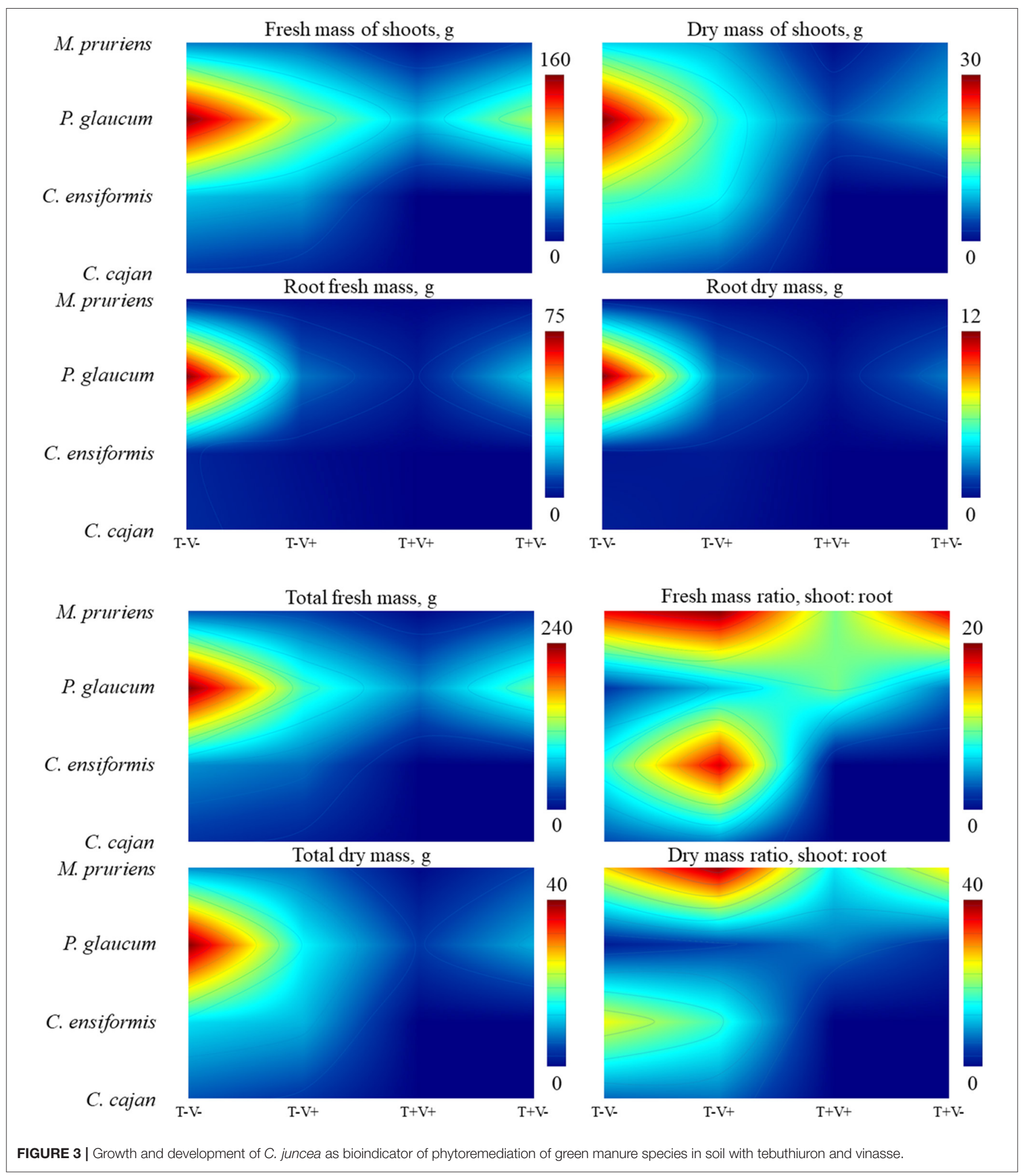

$\beta$ : inflection point;

$\kappa$ : specific-growth rate; $\alpha \kappa e^{-1}$ : absolute-growth rate;

$e$ : Euler number.
An unbiased soft computing technique of contour plotting was performed to chart the spatial production of phytomass by the models for green manure. To an optimization of visualization of non-Boolean patterns in chromatic wireframe by contour 
TABLE 3 | Performance of Crotalaria juncea after green manure species cultivation in soil with tebuthiuron and vinasse.

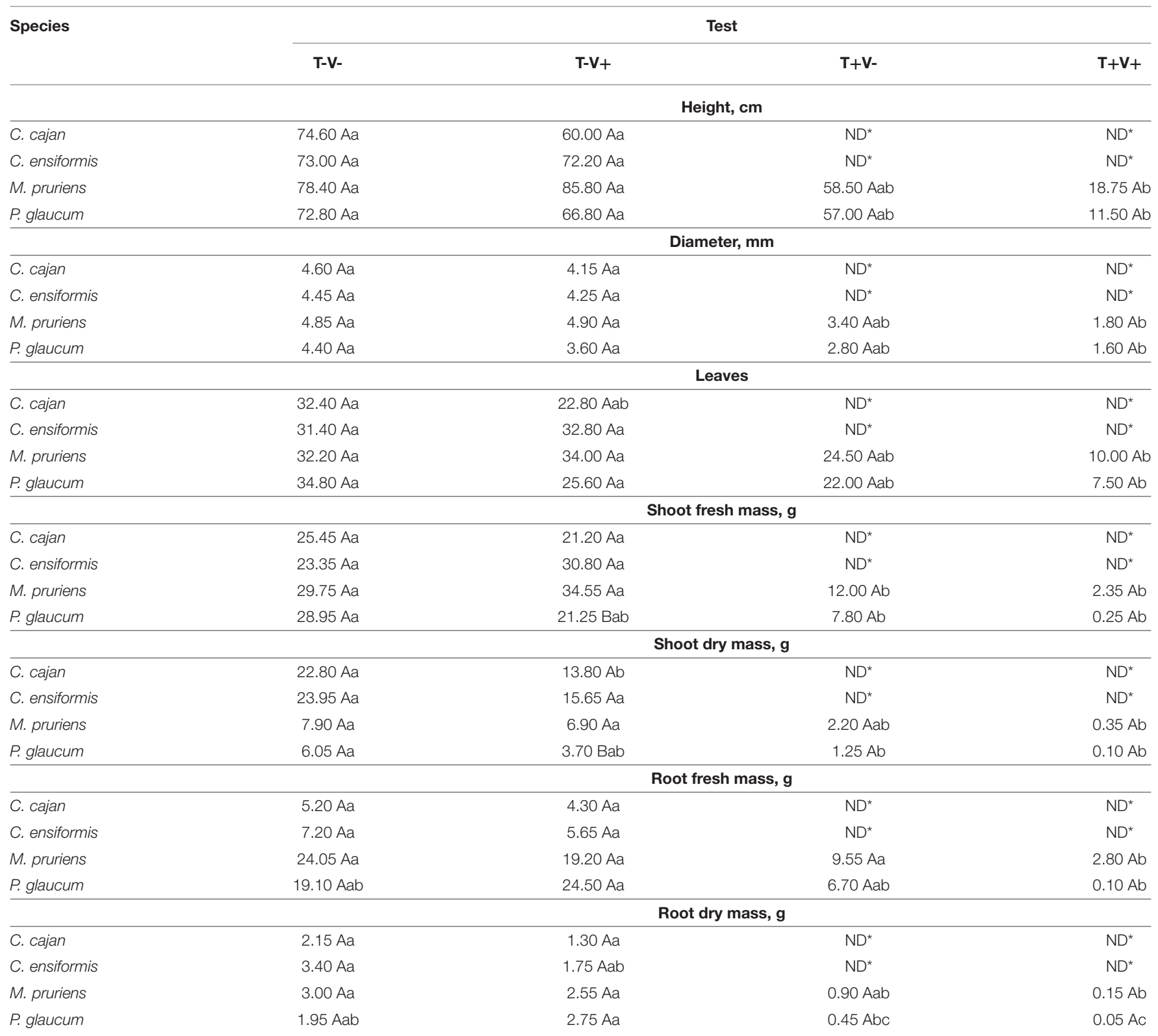

Same letters, whether uppercase in the column and lowercase in the row, describe statistically similar means by post hoc Tukey's HSD test at $p<0.05$;.

${ }^{*}$ As the plant dead, the trait became undetected (ND).

plotting approach, fuzzy logic to turn any ambiguity off from the data was implemented. Another method of applying nontraditional mathematics to establish an eventual effect of green manure on the decontamination of the soil included principal component analysis (PCA). The Kaiser-Meyer-Olkin test was applied to determine how many components should be necessary to reduce the high-dimensionality data, while preserving as much attributable variability as possible into orthogonal subsets without collinearities. The software was R-project. This multiparadigm programming open-coding language provides a user-friendly environment for statistical computing and graphs.

\section{RESULTS AND DISCUSSION}

\section{Performance of Species of Green Manure Morphological Traits}

The effects of green manure species and the microenvironment toward the phytoremediation potential was determined. Phytoremediators response occurred regardless of their morphological traits. The variations found in each assay allowed us to determine their sources (Table 1).

Tebuthiuron and vinasse underwent reactions in the soil, thus collectively influenced the phytotoxicity of the microclimate. 
TABLE 4 | Principal components into ecotoxicity bioassays in soil samples with green manure species, tebuthiuron and vinasse.

\begin{tabular}{|c|c|c|}
\hline Index/variable & \multicolumn{2}{|c|}{ Bartlett's test of sphericity } \\
\hline Chi-squared & \multicolumn{2}{|c|}{104.95} \\
\hline Degree of freedom & \multicolumn{2}{|c|}{10} \\
\hline \multirow[t]{4}{*}{$p$-value } & \multicolumn{2}{|c|}{$<0.01^{\star \star}$} \\
\hline & \multicolumn{2}{|c|}{ Kaiser-Meyer-Olkin test } \\
\hline & \multicolumn{2}{|c|}{ Component } \\
\hline & $\mathbf{P C}_{\mathbf{I}}$ & $\mathbf{P C}_{\|}$ \\
\hline Eigenvalue & $2.05^{\star}$ & $1.20^{\star}$ \\
\hline Percentage of variance & 42.75 & 25.45 \\
\hline \multirow[t]{2}{*}{ Cumulative percentage of variance } & 42.75 & 68.20 \\
\hline & \multicolumn{2}{|c|}{ Loading } \\
\hline Hypocotyl & 0.45 & $-0.55^{\star}$ \\
\hline Root & $0.95^{\star \star}$ & -0.05 \\
\hline$\% G$ & 0.05 & $0.90^{\star \star}$ \\
\hline$\% R$ & -0.35 & 0.25 \\
\hline \multirow[t]{2}{*}{ Gl } & $0.95^{\star \star}$ & 0.30 \\
\hline & \multicolumn{2}{|c|}{ Contribution, \% } \\
\hline Hypocotyl & 9.05 & $24.40^{\star}$ \\
\hline Root & $43.45^{\star \star}$ & 0.05 \\
\hline$\% G$ & 0.15 & $63.95^{\star \star}$ \\
\hline$\% R$ & 5.50 & 4.35 \\
\hline Gl & $41.85^{\star \star}$ & 7.25 \\
\hline
\end{tabular}

Significant code: ${ }^{\star *} p<0.01 ;{ }^{*} p<0.05$.

The herbicide alone was more toxic to $C$. cajan and $C$. ensiforms. In contrast, $M$. pruriens and P. glaucum resisted longer to chemically stressed microenvironment. Vinasse addition significantly reduced the toxicity. Hence, green manure species produced larger amounts of mass of roots and shoots in these soil samples (Figure 1).

Advantages of vinasse on the ecotoxicity were more prominent in $M$. pruriens and $P$. glaucum. These were the most effective strategies of manuring for phytoremediation potential. The primary assumption for vinasse attenuation by on phytotoxicity of soil may be its availability of soluble carbon. Thus, it is likely to power up the microbial metabolism and enhance the subsequent degradation of pesticides (Prata et al., 2000, 2001; Villaverde et al., 2008). Tebuthiuron is highly available and can move smoothly through the structure of agricultural soils with lows levels of organic matter and clay (Chang and Stritzke, 1977). These authors reported 40.00 and $1.00 \%$ herbicide adsorbed in particles at 4.8 and $0.30 \%$ organic matter, respectively. Bioavailability is one of the keys to an effective and consistent biodegradation. If the pollutant or contaminant is not available from the environment, (micro)organism cannot successfully perform longer. The nature and physicochemical properties of the pesticide (e.g., chemical stability, spatial structure, feedback effect, and intermediate metabolites) and its multiplicity of interactions with the rhizosphere are factors influencing greatly its bioavailability and, of course, kinetics of biodegradation.

\section{Kinetics of Growth and Development}

The Gompertz approach predicted accurately how long would it take for the chemical contamination of soil by tebuthiuron to become limiting for the growth and development of green manure species (Figure 2). Estimates for the absolute primary growth rate for the C. cajan in soil with tebuthiuron and vinasse combined was the lowest (Table 2). As long as the target molecule is rather persistent than readily degradable, the more probable the strategy of manuring is to inefficiently decontaminate an area. The highest estimations for both the maximum of size and absolute growth rate for this potential phytoremediator in soil with no tebuthiuron supported the high phytotoxicity of this herbicide to the primary growth.

In contrast, the association of tebuthiuron and vinasse allowed C. ensiformis to achieve its highest primary growth rate, whether specific or absolute. The negative estimation for absolute growth rate for this specie in soil with tebuthiuron alone was proof that vinasse was an effective source of nutrients to speed up the plant's growth and development, thus assisting in phytoremediation. The use of this agroindustrial residue also enhanced the height of $M$. pruriens and P. glaucum in soil samples with tebuthiuron. The herbicide severely limited the development of $C$. cajan and $C$. ensiformis, according to the lowest estimations for stem diameter. Thus, M. pruriens and P. glaucum are recommended over $C$. cajan and $C$. ensiforms for the phytoremediation of tebuthiuron in fields of sugarcane, even without the application of vinasse. The growth and development of C. juncea, the bioindicator chosen for this contaminant, became healthier and longer when sowing either $M$. pruriens and P. glaucum.

\section{Performance of $C$. juncea as Bioindicator of Phytoremediation}

The combination of tebuthiuron and vinasse considerably dropped the height, stem diameter, and number of leaves in $C$. juncea over time, compared to the control (Figure 3). In contrast, the herbicide alone had no significant effect, whether negative or positive, on the growth and development by the bioindicator species sowed after growing green manure species, consistent with the outcomes of explanatory analysis.

The explanation for the extensive decrease in leaves production (Table 3) may be either phytotoxicity by the compounds at high concentrations in soil or natural senescence, as plants become metabolically and physiologically ineffective over time. In contrast, the control soil sample (without tebuthiuron and vinasse) peaked in height, stem diameter, and number of leaves. Therefore, C. juncea was highly susceptible to tebuthiuron. Practically, this molecule more severely disabled both $C$. cajan and $C$. ensiformis to grow and develop as healthily as possible prior to sowing C. juncea for monitoring the potential phytoremediation of soil with green manure.

The behavior of bioindicator species C. juncea supported how persistent should be tebuthiuron in a microenvironment, 


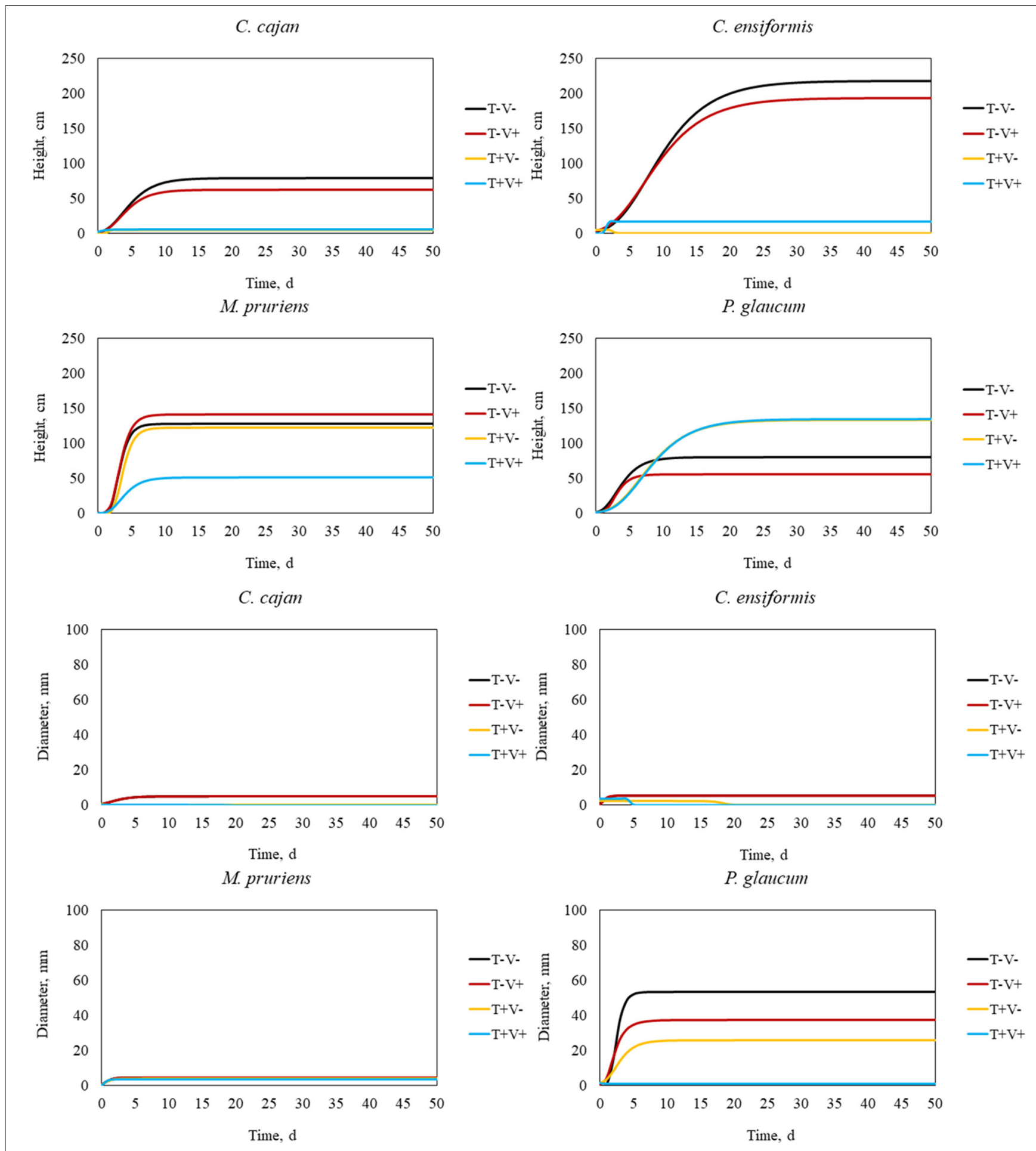

FIGURE 4 | Principal components into the ecotoxicity bioassays after 50 days of cultivation of green manure species in soil with tebuthiuron and vinasse.

regardless of vinasse application as source of nutrients to speed up the growth and development and, hence, assist green manure species in extensively remediating the herbicide.
C. cajan and C. ensiformis ended up much more effectively remediating tebuthiuron and, hence, ensured the soil more suitable for the bioindicator species' growth and development 
(Pires et al., 2008), inconsistent with the trends in this study. Some plants are capable of highly remediating contaminants (Ferraço et al., 2017). Cultivation of C. juncea slightly reduced sulfentrazone concentration in soil. Bioindicators of this herbicide then grew more consistently over time, regardless of sowing density, but not as consistent as control assay (Ferraço et al., 2019).

Franco et al. (2014) reported phytoremediation benefits by Phaseolus vulgaris on the growth and development of Urochloa brizantha. Plant heigh, leaf production, and area all increased in $C$. juncea with decreasing concentration of contaminant. Thus, the longer the postcultivation is, the more probable the phytoremediation is to becoming effective.

Beans in soil with picloram at $32.00 \mathrm{~g} \mathrm{ha}^{-1}$ produced low amount of dry mass due to plants' death at high pesticide concentration. However, this morphological trait increased with phytoremediation by the Urochloa sp. (Franco et al., 2015). Belo et al. (2016) reported similar trend for the dry mass of P. glaucum after phytoremediation by $C$. juncea and $C$. ensiformis. Data on phytoremediation potential of herbicides, like sulfentrazone, by $P$. glaucum are neither conclusive nor conducive to commercial application yet, and this requires further investigations (Madalão et al., 2012a,b). These references supported the major findings in this study on the negative effect of tebuthiuron on biomass accumulation in roots and shoots of green manures species. Other reliable and executable bioindicators of soil decontamination are finger millet (Eleusine cocracana), for chlorimuron-ethyl and sulfumeturonmethyl (Assis et al., 2010), and cucumber for picloram (Galon et al., 2017).

\section{Ecotoxicity Bioassays}

The principal component analysis robustly reduced the dimensionality of dataset and preserved as much interpretable variability as possible into the components, $\mathrm{PC}_{\mathrm{I}}$ and $\mathrm{PC}_{\mathrm{II}}$. These components, collectively, explained $\sim 70.00 \%$ variance in ecotoxicity of soil samples on germination, growth, and development of the test-organism $L$. sativa (Table 4).

The first component, attributable to seed physiological vigor, had positive correlations with hypocotyl length and germination index (GI). Cartesian coordinates for soil samples with phytoremediation by either $M$. pruriens and $P$. glaucum structurally were positive in the upper right quadrant in the factorial map (Figure 4). Therefore, the more effective the tebuthiuron biodegradation is, the less probable the contaminant is to become toxic during the germination and primary growth of $L$. sativa seeds. The second component, attributable to physiological anomaly by phytotoxicity, had positive and negative loadings with germination and hypocotyl length, respectively. Soil samples with $P$. glaucum and hypocotyl were closer together in the lower right quadrant. Thus, this species should be of greater relevance to ensure plant growing and development without any severe physiological anomaly by tebuthiuron in site without vinasse.

\section{CONCLUSION}

Green manure species and vinasse can remediate soils with tebuthiuron. Preliminary evidence of $M$. pruriens and P. glaucum show their increased capabilities of phytoremediating sites where the target herbicide exists. These species, in association with vinasse as source of soluble carbon, can decontaminate the system more effectively than C. cajan and C. ensiformis, thus enabling the bioindicator $C$. juncea to grow and develop healthier in the presence of residual tebuthiuron. As long as the manuring by fertilizing agents is effective in remediating the soil, the less probable tebuthiuron persists at high concentrations in soil and, thus, becoming harmful to non-target organisms as shown in ecotoxicity bioassays. Undergerminated seeds and severe physiological anomalies due to phytotoxicity in roots and hypocotyl of $L$. sativa are likely to decrease quickly with phytoremediation by $M$. pruriens and $P$. glaucum, which is the best chance to do this. Findings of this study are timely and should be of great importance to development and implementation of cost-effective strategies to assist in mitigating contamination of soil by tebuthiuron in sugarcane crops with vinasse application as biofertilizer. The fate of this herbicide and its potential metabolites in soil and into tissues of green manure species, especially $M$. pruriens and P. glaucum, is prone to scaled up designs toward an effective and safe industrial usage and could be the focus of further investigations.

\section{DATA AVAILABILITY STATEMENT}

The raw data supporting the conclusions of this article could be made available by the authors.

\section{AUTHOR CONTRIBUTIONS}

LF, EP, RT, EB, and PL: conceptualization. LF, RM, YF, and PL: methodology. LF, BM, RM, RV, and PL: validation. LF, BM, and PL: formal analysis, data curation, and writing-original draft. LF and YF: investigation. PL: resources, supervision, project administration, and funding acquisition. RM, EP, RV, RT, JC, EB, YF, and PL: writing-review \& editing. BM, JC, and PL: visualization. All authors contributed to the article and approved the submitted version.

\section{FUNDING}

This work was supported by Coordination of Superior Level Staff Improvement (CAPES, Brazil) and Pró-Reitoria de PósGraduação da Unesp (Brazil). 


\section{REFERENCES}

ABNT, Associação Brasileira de Normas Técnicas (2004). NBR 10006: Procedure for Obtaining Solubilized Solid Waste Extract (NBR 10006: Procedimento Para Obtenção De Extrato Solubilizado De Resíduos Sólidos). Rio de Janeiro: ABNT, 7.

Ali, H., Khan, E., and Sajad, M. A. (2013). Phytoremediation of heavy metals - concepts and applications. Chemosphere 91, 869-881. doi: 10.1016/j.chemosphere.2013.01.075

Andrade, J. M. F. (2007). Environmental Impacts of Sugarcane Agroindustry: Subsidies for Management (Impactos ambientais da agroindústria da canade-açúcar: subsídios para a gestão). São Paulo: Monography, University of São Paulo, 131 .

Assad, L. (2017). Use of waste from the sugar and alcohol sector challenges companies and researchers (Aproveitamento de resíduos do setor sucroalcooleiro desafia empresas e pesquisadores). Ciência e Cult. 69, 13-16. doi: 10.21800/2317-66602017000400005

Assis, R. L., Procópio, S. O., Carmo, M. L., Pires, F. R., Cargnelutti Filho, A., and Braz, G. B. P. (2010). Phytoremediation of soil contaminated with the herbicide picloram by Indian goosegrass (Fitorremediação de solo contaminado com o herbicida picloram por plantas de capim pé de galinha gigante). Rev. Brasil. Eng. Agrícol e Ambiental 14, 1131-1135. doi: 10.1590/S1415-43662010001100001

Banks, M. K., and Schultz, K. E. (2005). Comparison of plants for germination toxicity tests in petroleum-contaminated soils. Water Air Soil Pollut. 167, 211-219. doi: 10.1007/s11270-005-8553-4

Belo, A. F., Pires, F. R., Bonomo, R., Cargnelutti Filho, A., and Tenis, L. H. O. (2016). Sulfentrazone phytoremediation under field conditions. Rev. Caat. 29, 119-126. doi: 10.1590/1983-21252016v29n114rc

Breitenbach, J., Zhu, C., and Sandman, G. (2001). Bleaching herbicide norflurazon inhibits phytoene desaturase by competition with the cofactors. J. Agricul. Food Chem. 49, 5270-5272. doi: 10.1021/jf0106751

Chang, S. S., and Stritzke, J. J. (1977). Sorption, movement and dissipation of tebuthiuron in soils (Sorção, movimento e dissipação do tebutiuron nos solos). Weed Sci. 25, 184-187.

Christofoletti, C. A., Sousa, C. M., Souza, R. B., Francisco, A., and Gastaldi, V. D. (2017). The use of different residues used as fertilizers in sugarcane cultivation (O emprego de diferentes resíduos utilizados como fertilizantes na cultura de cana-de-açúcar). In: Sugarcane and its impacts: an academic view (Cana-de-açúcar e seus impactos: uma visão acadêmica). Bauru: Canal 6, 275 p.

Fasanella, C. C., and Cardoso, E. J. B. N. (2016). "Bioremediation. (Biorremediação)," in Soil Microbiology (Microbiologia do solo). F.D Andreote and E. J. B. N. Cardoso 2ed. Piracicaba: ESALQ 1, 197-210.

Ferraço, M, Pires, F. R., Belo, A. F., Celin Filho, A., and Bonomo, R. (2017). Effect of population density of Canavalia ensiformis on phytoremediation of soil contaminated with sulfentrazone (Efeito da densidade populacional de Canavalia ensiformis na fitorremediação de solo contaminado com sulfentrazone). Rev. Ciênc. Agron. 48, 32-40. doi: 10.5935/1806-6690.20170004

Ferraço, M., Belo, A. F., Madalão, J. C., Pires, F. R., and Celim Filho. (2019). The residues of Canavalia ensiformis and Crotalaria juncea after phytoremediation in soil contaminated with sulfentrazone do not result in soil recontamination. Rev. Cienc. Agrár. 14:e5638. doi: 10.5039/agraria.v14i2a5638

Ferro, A. M., Sims, R. C., and Bugbee, B. (1994) Hycrest crested wheatgrass accelerates the degradation of pentachlorophenol in soil. J. Environ. Q. 23, 272-279. doi: 10.2134/jeq1994.00472425002300020008x

Franco, M. H. R., França, A. C., Albuquerque, M. T., Schiavon, N. C., and Vargas, G. N. (2014). Phytoremediation of soils contaminated with picloram by Urochloa brizantha. Pesq. Agrop. Trop. 44, 460-467. doi: 10.1590/S1983-40632014000400003

Franco, M. H. R., Lemos, V. T., Aguiar, L. M., França, A. C., Ferreira, E. A., and Silva, D. V. (2015). Physiological characteristics of bean cultivated in soils after phytoremediation of picloram (Características fisiológicas do feijoeiro cultivado em solos após fitorremediação do picloram). Rev. Brasil. Herb. 14, 315-325. doi: 10.7824/rbh.v14i4.454

Franco-Bernardes, M. F., Maschio, L. R., Oliveira, M. T. V. A., and Almeida, E. A. (2014). Biochemical and genotoxic effects of a commercial formulation of the herbicide tebuthiuron in Oreochromis niloticus of different sizes. Ecotoxicol. Environ. Contam. 9, 59-67. doi: 10.5132/eec.2014.01.008
Galon, L., Nonemacher, F., Agazzi, L. R., Fiabane, R. C., Forte, C. T., Franceschetti, M. B., et al. (2017). hytoremediation of soil contaminated with FSII and ALS-inhibiting herbicides (Fitorremediação de solo contaminado com herbicidas inibidores de FSII e de ALS). Rev. Brasil. Herb. 16, 307-324. doi: 10.7824/rbh.v16i4.586

Köppen, W. (1948). Climatology: Study of te Earth Climates (Climatologia: Conunestudio De Los Climas De Latierra). Pánuco: Fondo de Cultura Econômica, 479.

Koskinen, W. C., Stone, D. M., and Harris, A. R. (1996). Sorption of hexazinone, sulfometuron methyl, and tebuthiuron on acid, low base saturated sands. Chemosphere 32, 1681-1689. doi: 10.1016/0045-6535(96)00085-9

Kuva, M. A., Ferraudo, A. S., Pitelli, R. A., Alves, P. L. C. A., and Salgado, T. P. (2008). Infestation patterns of weed communities in raw cane agroecosystem (Padrões de infestação de comunidades de plantas daninhas no agroecossistema de cana-crua). Planta Dan. 26, 549-557. doi: 10.1590/S0100-83582008000300010

Labouriau, L. G., and Agudo, M. (1987). On the physiology of seed germination in Salvia hispanica L. I. Temperature Effects. Anais da Acad. Brasi. Ciências $59,37-56$.

Madalão, J. C., Pires, F. R., Cargnelutti Filho, A., Chagas, K., Nascimento, A. F., and Garcia, G. O. (2012b). Phytoremediation of soils contaminated with the herbicide sulfentrazone by green manure species (Fitorremediação de solos contaminados com o herbicida sulfentrazone por espécies de adubos verdes). Rev. Cienc. Agrár. 55, 288-296. doi: 10.4322/rca.2012.068

Madalão, J. C., Pires, F. R., Cargnelutti Filho, A., Nascimento, A. F., Chagas, K., Araújo, R. S., et al. (2013). Susceptibility of plant species with phytoremediation potential of the herbicide sulfentrazone (Susceptibilidade de espécies de plantas com potencial de fitorremediação do herbicida sulfentrazone). Rev. Ceres 60, 111-121. doi: 10.1590/S0034-737X2013000100016

Madalão, J. C., Pires, F. R., Chagas, K., Cargnelutti Filho, A., and Procópio, S. O. (2012a). Use of legumes in phytoremediation of soil contaminated with sulfentrazone (Uso de leguminosas na fitorremediação de solo contaminado com sulfentrazone). Pesqu. Agrop. Trop. Goiânia 42, 390-396. doi: 10.1590/S1983-40632012000400001

Madalão, J. C., Pires, F. R., Nascimento, A. F., Chagas, K., Cargnelutti Filho, A., and Oliveira Procópio, S. (2016). Phytoremediation of soil contaminated with sulfentrazone as a function of the cultivation time of Canavalia ensiformis (Fitorremediação de solo contaminado com sulfentrazone em função do tempo de cultivo de Canavalia ensiformis).Rev.Agro@mbiente 10,36-43.

Melo, C. A. D., Souza, W. M. D., Carvalho, F. P. D., Massenssini, A. M., Silva, A. A. D., Ferreira, L. R., et al. (2017). Microbial activity of soil with sulfentrazone associated with phytoremediator species and inoculation with a bacterial consortium. Bragantia 75 300-310. doi: 10.1590/1678-4499.203

Moraes, D. A. C., Spadotto, C. A., Sartori, A. A. C., and Zimback, C. R. L. (2016). Spatial variability of the risk of groundwater contamination by tebuthiuron in a sugarcane area (Variabilidade espacial do risco de contaminação de águas subterrâneas por tebuthiuron em área de cana-de-açúcar). Pesq. Agrop. Brasil. 51, 1992-1999. doi: 10.1590/s0100-204x2016001200010

Oliveira, M. F., and Brighenti, A. M. (2011). "Herbicides behavior in environment (Comportamento dos herbicidas no ambiente)," in Biologia e manejo de plantas daninhas, eds J. R. Oliveira, R. S. Constantin, J. Inoue, M. H. Edição. Curitiba: Ominipax, 263-304.

Pires, F. R., de Oliveira Procópio, S., de Souza, C. M., dos Santos, J. B., and Silva, G. P. (2006). Green manures in phytoremediation of soils contaminated with the herbicide tebuthiuron (Adubos verdes na fitorremediação de solos contaminados com o herbicida tebuthiuron). Rev. Caatinga 19, 92-97.

Pires, F. R., Oliveira Procópio, S. D., Barbosa Dos Santos, J., Souza, C. M. D., and Dias, R. R. (2008). Phytoremediation evaluation of tebuthiuron using Crotalaria juncea as an indicator plant (Avaliação da fitorremediação de tebuthiuron utilizando Crotalaria juncea como planta indicadora). Rev. Ciênc. Agron. 39, 245-250.

Pires, F. R., Souza, C. M., Silva, A. A., Cecon, P. R., Procópio, S. O., Santos, J. B., et al. (2005). Phytoremediation of soil contaminated with tebuthiuron using green manure species (Fitorremediação de solos contaminados com tebuthiuron utilizando-se espécies cultivadas para adubação verde). Planta Daninha 23, 711-717. doi: 10.1590/S0100-83582005000400020 
Pires, F. R., Souza, C. M., Silva, A. A., Queiroz, M. E. L. R., Procópio, S. O., Santos, J. B., et al. (2003). Selection of plants with potential for phytoremediation of tebuthiuron. (Seleção de plantas com potencial para fitorremediação de tebuthiuron) Planta Da. 21, 451-458. doi: 10.1590/S0100-835820030003 00014

Prata, F., Lavorenti, A., Regitano, J. B., and Tornisielo, V. L. (2000). Degradation and adsorption of diuron in soils treated with vinasse (Degradação e adsorção de diuron em solos tratados com vinhaça). Rev. Brasil. Ciências do Solo 24, 217-223. doi: 10.1590/S0100-06832000000100024

Prata, F., Lavorenti, A., Regitano, J. B., and Tornisielo, V. L. (2001). Ametrine degradation and sorption in two soils with vinasse application (Degradação e sorção de ametrina em dois solos com aplicação de vinhaça). Pesquisa Agropecuária Brasileira 36, 975-981. doi: 10.1590/S0100-204X200100070 0007

Rocha, R. S., Beati, A. A. G. F., Valim, R. B., Steter, J. R., Bertazzoli, R., and Lanza, M. R. V. (2018). Evaluation of degradation by-products of the herbicide ametrine obtained via advanced oxidative processes. (Avaliação dos subprodutos de degradação do herbicida ametrina obtidos via processos oxidativos avançados). Rev. Brasil. Engenh. Biossistemas 12, 52-67. doi: 10.18011/bioeng2018v12n1p52-67

Rodrigues, B. N., and Almeida, F. S. (2011). Herbicides guide. (Guia de herbicidas). 6.ed., v.1. Londrina: IAPAR.

Sandaniel, C. R., Fernandez, L. B., and Barroso, A. L. L. (2008). Sugarcane weed control with herbicides applied in pre-emergence (Controle de plantas daninhas em cana soca com herbicidas aplicados em pré-emergência). Núcleos 5, 1-10. doi: 10.3738/nucleus.v5i2.85

Santos, H. G., Jocomine, P. K. T., Anjos, L. H. C., Oliveira, V. A., Lumbrearas, J. F., Coelho, M. R., et al. (2018). Brazilian system of soil classification (Sistema Brasileiro de Classificação de Solos). Rio de Janeiro: Embrapa. 5 ed. rev. ampli. 531.

Sobrero, M. C., and Ronco, A. (2004). "Acute toxicity test with lettuce seeds. (Lactuca sativa L.). (Ensayo de toxicidad aguda con semillas de lechuga (Lactuca sativa L.))," in Toxicological tests and water quality assessment methods: standardization; intercalibration; results and applications. (Ensayos toxicológicos y métodos de evaluación de calidad de aguas: standerización; intercalibración; resultados y aplicaciones), ed G. C. Morales (Mexico: IMTA), 71-79.

Souza, L. A. D., Andrade, S. A. L. D., Souza, S. C. R. D., and Schiavinato, M. A. (2011). Tolerance and phytoremediation potential of Stizolobium aterrimum associated with the arbuscular mycorrhizal fungus Glomus etunicatum in soil contaminated by lead. (Tolerância e potencial fitorremediador de Stizolobium aterrimum associada ao fungo micorrízico arbuscular Glomus etunicatum em solo contaminado por chumbo). Rev. Brasil. Ciências do Solo 35, 1441-1451. doi: 10.1590/S0100-06832011000400038

Vasconcellos, M. C., Pagliuso, D., and Sotomaior, V. S. (2012). Phytoremediation: A proposal for soil decontamination. (Fitorremediação: Uma proposta de descontaminação do solo). Estud. Biol. 34, 261-267. doi: 10.7213/estud.biol.7338

Victoria Filho, R., and Christoffoleti, P. J. (2004). Weed management and sugarcane productivity (Manejo de plantas daninhas e produtividade da cana). Visão Agrícola 3, 32-37.

Villaverde, J., Kah, M., and Brown, C. D. (2008). Adsorption and degradation of four acidic herbicides in soils from southern Spain. Pest Manag. Sci. Oxford 64, 703-710. doi: $10.1002 /$ ps. 1545

Conflict of Interest: The authors declare that the research was conducted in the absence of any commercial or financial relationships that could be construed as a potential conflict of interest.

Copyright (c) 2021 Ferreira, Moreira, Montagnolli, Prado, Viana, Tomaz, Cruz, Bidoia, Frias and Lopes. This is an open-access article distributed under the terms of the Creative Commons Attribution License (CC BY). The use, distribution or reproduction in other forums is permitted, provided the original author(s) and the copyright owner(s) are credited and that the original publication in this journal is cited, in accordance with accepted academic practice. No use, distribution or reproduction is permitted which does not comply with these terms. 